\title{
ASSESSMENT IN PRIMARY SCHOOL MATHEMATICS EDUCATION IN BRAZIL'
}

\author{
JUTTA CORNELIA REUWSAAT JUSTO ${ }^{1}$ \\ ORCID: https://orcid.org/0000-0001-5110-1571 \\ EDNEI LUÍS BECHER ${ }^{2}$ \\ ORCID: https://orcid.org/0000-0001-8770-2424 \\ MARJA VAN DEN HEUVEL-PANHUIZEN ${ }^{3 ; 4}$ \\ ORCID: https://orcid.org/0000-0002-3985-7576 \\ MICHIEL VELDHUIS ${ }^{5 ; 3}$ \\ ORCID: https://orcid.org/0000-0001-5940-039X
}

\begin{abstract}
In this study, we aimed to gain further knowledge about Brazilian primary school teachers' assessment practices and beliefs in mathematics education. For this, we carried out an analysis of curriculum documents and reviewed recent research literature on assessment in Brazil, permitting us to answer the following research question: How are the mathematics assessment practices and teachers' beliefs, as revealed in recent research, and how are these related to the conceptualization of assessment in Brazilian mathematics curriculum documents? We found that teachers' assessment practices, as described in the reviewed research between 2010 and 2017, did, in general, not reflect the conceptualization of assessment in the curriculum documents. Furthermore, despite that the beliefs of most teachers on assessment reflected it to be a process to improve teaching and learning, their mathematics assessment practices did not favor assessment for learning. Still, they were mostly used as an instrument to determine students' classification. We recommend a public policy in which teachers are offered opportunities for professional development, focusing on formative assessment in mathematics education.
\end{abstract}

Keywords: Classroom assessment, Large-scale assessment, Brazilian research, Mathematics education, Primary school.

\section{AVALIAÇÃO EM EDUCAÇÃO MATEMÁTICA NOS ANOS INICIAIS NO BRASIL}

RESUMO: Neste estudo, procuramos obter mais conhecimento sobre as práticas e as crenças em relação à avaliação em educação matemática de professores dos anos iniciais. Realizamos uma análise dos documentos curriculares e revisamos a literatura recente sobre pesquisas em avaliação no Brasil,

\footnotetext{
${ }^{1}$ Universidade Luterana do Brasil - ULBRA/Canoas, Programa de Pós-Graduação em Ensino de Ciências e Matemática PPGECIM. Canoas, RS, Brasil.<juttareuw@gmail.com>

${ }^{2}$ Universidade Luterana do Brasil - ULBRA/Canoas, Programa de Pós-Graduação em Ensino de Ciências e Matemática PPGECIM. Canoas, RS, Brasil. <edneibecher@gmail.com>

${ }^{3}$ Utrecht University, Utrecht, the Netherlands

${ }^{4}$ Nord University, Bodø, Norway. <m.vandenheuvel-panhuizen@uu.nl>

5 iPabo University of Applied Sciences, Amsterdam/Alkmaar, Netherlands.<m.veldhuis@uu.nl> Educação em Revista|Belo Horizonte|v.36|e212670|2020
} 
respondendo a seguinte questão de pesquisa: Como são as práticas de avaliação matemática e as crenças dos professores, reveladas em pesquisas recentes, e como essas estão relacionadas à conceituação de avaliação em documentos curriculares brasileiros? Verificamos que as práticas de avaliação dos professores, conforme pesquisas revisadas entre 2010 e 2017, em geral não refletiam a conceitualização da avaliação apresentada nos documentos curriculares. Apesar da maioria dos professores conjeturarem que a avaliação seja um processo para melhorar o ensino e a aprendizagem, suas práticas de avaliação em matemática não favoreciam a avaliação para aprendizagem, mas foram usadas principalmente como um instrumento para determinar a classificação dos alunos. Recomendamos uma política pública de formação de professores na qual sejam oferecidas oportunidades de desenvolvimento profissional com foco na avaliação formativa em educação matemática.

Keywords: Avaliação em sala de aula, Avaliação em larga escala, Pesquisa brasileira, Educação matemática, Anos Iniciais.

\section{EVALUACIÓN EN EDUCACIÓN MATEMÁTICA EN LA ESCUELA PRIMARIA EN BRASIL}

RESÚMEN: En este estudio se busca obtener un mayor conocimiento sobre prácticas y creencias en relación a la evaluación en educación matemática de docentes de primaria. Realizamos un análisis de los documentos curriculares y revisamos la literatura reciente sobre investigación en evaluación en Brasil, respondiendo a la siguiente pregunta de investigación: ¿Cuáles son las prácticas de evaluación matemática y las creencias de los docentes, reveladas en investigaciones recientes, y cómo se relacionan con la conceptualización? evaluación en documentos curriculares brasileños? Encontramos que las prácticas de evaluación de los docentes, según encuestas revisadas entre 2010 y 2017, en general no reflejaban la conceptualización de la evaluación presentada en los documentos curriculares. Aunque la mayoría de los profesores conjeturan que la evaluación es un proceso para mejorar la enseñanza y el aprendizaje, sus prácticas de evaluación en matemáticas no favorecieron la evaluación para el aprendizaje, sino que se utilizaron principalmente como un instrumento para determinar las calificaciones de los estudiantes. Recomendamos una política pública de formación docente en la que se ofrezcan oportunidades de desarrollo profesional con un enfoque en la evaluación formativa en educación matemática.

Palabras clave: Evaluación en el aula, Evaluación a gran escala, Investigación brasileña, Educación Matemática, Escuela primária.

\section{INTRODUCTION}

In the last half of the 20th century, in many countries around the world, educational reforms have taken place. Most of these educational reforms also advocated an assessment reform (Berry, 2011), promoting the view of assessment as an ongoing process interconnected with teaching and learning (e.g., Shepard, 2000; Suurtamm, Koch, \& Arden, 2010; Van den Heuvel-Panhuizen, 1996; Van den Heuvel-Panhuizen \& Becker, 2003). This means that assessment "is a complex, allencompassing process that fulfills a central role in instruction" (Veldhuis \& Van den HeuvelPanhuizen, 2014, p. 3). However, not all studies that investigated the implementation of this approach to assessment came to positive findings. Berry (2011) concluded that, following such reforms, only limited changes in teachers' assessment practices were found, as shown by the continuing emphasis on grading students and little focus on supporting their learning.

Also, in Brazil, reform in education and assessment took place. The National Curriculum Parameters (Parâmetros Curriculares Nacionais - PCN; Ministério da Educação, 1997) meant to provide schools and school systems with indications for elaborating their own curriculum and emphasized that, in addition to large-scale assessment, there should be more attention for classroom assessment. This assessment was understood as "a part of the process of teaching and learning" 
(Ministério da Educação, 1997, p. 20). However, currently, over two decades after the publication of this document, it is still not entirely clear whether and how this broad interpretation of assessment, in which large-scale assessment and classroom assessment are both deemed important, has found its way into primary school classrooms in Brazil.

When investigating teachers' assessment practices and their beliefs on assessment, Costa (2013) conducted a literature review of publications addressing assessment in primary school mathematics education. The publications in Costa's review were found in databases, including papers presented at scientific conferences in Brazil, master's dissertations, and doctoral theses. The reviewed publications appeared between 2000 and 2012. The conference papers showed that research into the assessment of primary school mathematics had scarcely been carried out in Brazil. Only 12 articles (less than $1 \%$ of the total number of papers) dealt with this topic. Furthermore, only 14 master's dissertations and 1 Ph.D. thesis were published between 2000 and 2009 on the subject of assessment. The general conclusion of Costa (2013) was that in the Brazilian research on mathematics assessment in primary school, there is a strong focus on large-scale assessment and that classroom assessment is a missing topic.

Large-scale assessments in Brazil, since 1990, mainly concern the National Basic Education Assessment System (SAEB), which is aimed to assess the quality of instruction delivered by the Brazilian basic education system and currently contains the following examinations: National Assessment of Basic Education (Aneb), the National Assessment of School Performance (Anresc), known as Prova Brasil, and the Assessment National Literacy (ANA). Brazil also uses large-scale assessments for monitoring education and identifying factors influencing student performance. These monitoring assessments investigate the proficiency of students in Portuguese and Mathematics, focusing respectively on reading and problem-solving. Another type of large-scale assessment is the Provinha Brasil of Mathematics, which is meant to be used as a pedagogical tool with no classificatory purposes. The main objective of this test is to provide information to teachers, managers, and teaching networks on the level of reading and mathematical literacy of students in the second year of schooling. The Provinha Brasil is administered at the beginning and the end of the school year. Besides, it can be controlled and corrected by the classroom teachers so that the teachers have immediate access to the results obtained by their students. These large-scale national examinations and monitoring assessments are elaborated by the National Institute for Educational Studies and Research (INEP). In addition to the national assessment system, some states of the Brazilian federation also elaborate on their evaluation systems, such as the Assessment System of School Learning of the state of São Paulo (SARESP).

In the current study, we wanted to gain further knowledge about how Brazilian primary school teachers perform and conceive assessment in mathematics education and how teachers' assessment practices and beliefs are related to the conceptualizations of assessment in the Brazilian mathematics curriculum. For this, we carried out an analysis of curriculum documents and an updated review of research literature on assessment in Brazil. Our scope in this research on assessment was broad and included both large-scale external assessment and classroom assessment for which the teacher is responsible. Our leading research questions were:

a) How is assessment in the Brazilian mathematics curriculum documents for primary school conceptualized?

b) What does recent research reveal about Brazilian primary school mathematics assessment practices and teachers' beliefs?

c) How are the mathematics assessment practices and teachers' beliefs, as revealed in recent research, related to how assessment is conceptualized in the Brazilian mathematics curriculum documents?

\section{METHOD}


We conducted exploratory qualitative research through descriptive methods and analyses, covering document analysis, literature review, and establishing relations between the documents and the literature review that were carried out.

\section{Curriculum Documents Analysis}

To know how assessment in the Brazilian mathematics curriculum for primary school is conceptualized, we analyzed documents describing the Brazilian mathematics curriculum. We selected the curriculum documents that were in effect when the papers included in the literature review were published between 2010 and 2017 (see Section 2.2). After identifying possible relevant documents (PCN and Reference Matrices), we examined them to identify the excerpts in which the intended assessment practice was highlighted. By doing this, we assembled an overview of the mathematics assessment principles, conceptions, and guidelines for the assessment practice in primary school.

In the end, the relevant excerpts were only found in the PCN (Ministério da Educação, 1997). The Ministry of Education published the PCN for the area of mathematics in primary school in 1997. This document was developed based on principles from national and international studies, research, debates, and practices developed in the 1980s and 1990s. These principles include among others: the mathematics must be within reach for all students, as knowledge to understand reality; the classroom environment must encourage students to create, compare, discuss, review, ask, and extend mathematical solutions; communication should be encouraged, leading students to speak and write about mathematics; and learning mathematics requires understanding and assigning meaning.

The PCN describe the poor performance of Brazilian students in large-scale assessments and warns that changes had to be made in mathematics teaching because students failing this discipline is the reason for most school dropouts and retention. Regarding mathematics instruction, the PCN state that it is fundamental to be clear for teachers their conceptions of mathematics, classroom practice, pedagogical choices, and their objectives and contents of teaching.

As such, the PCN aim to establish a curriculum reference supporting the revision and drafting of curricula in Brazilians' states and schools. The PCN were the only official national document guiding the curriculum over the last 20 years in the entire Brazilian educational system but did not constitute a mandatory curriculum ${ }^{6}$.

\section{Literature Review}

To investigate what recent research reveals about Brazilian primary school mathematics assessment practices and teachers' beliefs, we built on Costa's (2013) study and continued where she ended her literature review. This means that our review covered publications on assessment that were published between 2010 and 2017. The search for and selection of relevant publications was carried out in September and October 2017.

First, we examined the proceedings of Brazilian scientific conferences on mathematics education and educational assessment. We started with the proceedings of two conferences that are governed by the Brazilian Society of Mathematics Education: the International Seminar of Research in Mathematics Education ${ }^{7}$ and the National Meeting of Mathematics Education ${ }^{8}$. Then, we examined the proceedings of two independent educational research conferences: the National Meeting of the National Association of Post-Graduate Research in Education ${ }^{9}$ and the National Congress of Educational Assessment ${ }^{10}$. Finally, we searched for relevant publications in the national database of

\footnotetext{
${ }^{6}$ From 2014 onwards, a reform process started to formulate a Common National Curriculum Base (Ministério da Educação, 2017), which is expected to be effective in 2020, consisting of a normative document that defines the set of essential skills and understandings that students should develop in basic education.

${ }^{7}$ http://www.sbembrasil.org.br/sbembrasil/index.php/anais/sipem

${ }^{8} \mathrm{http}: / /$ www.sbembrasil.org.br/sbembrasil/index.php/anais/enem

${ }^{9} \mathrm{http}: / /$ www.anped.org.br/reunioes-cientificas/nacional

10 http://wwwp.fc.unesp.br/\#!/conave 
Ph.D. theses and master's dissertations ${ }^{11}$. All the queries that were carried out consisted of the keywords "Assessment", "Mathematics", and "Primary School" in the title, the keywords, and the abstract.

In continuity, we read the titles and abstracts that resulted in all these search queries. Based on this reading, we identified 54 publications that addressed assessment in primary school mathematics education. Among which 34 papers from conference proceedings and 20 dissertations and theses. In this step, we separated the texts according to the themes of large-scale assessment or classroom assessment.

As a next step, we read the full papers. The publications addressing textbook analyses and sociological analyses were excluded because we focused only on assessment practices. This resulted in 20 publications that were rearranged according to their theme, data source, and focus (Figure 1).

Figure 1. Middle step: Publications according to their theme, data source, and focus.

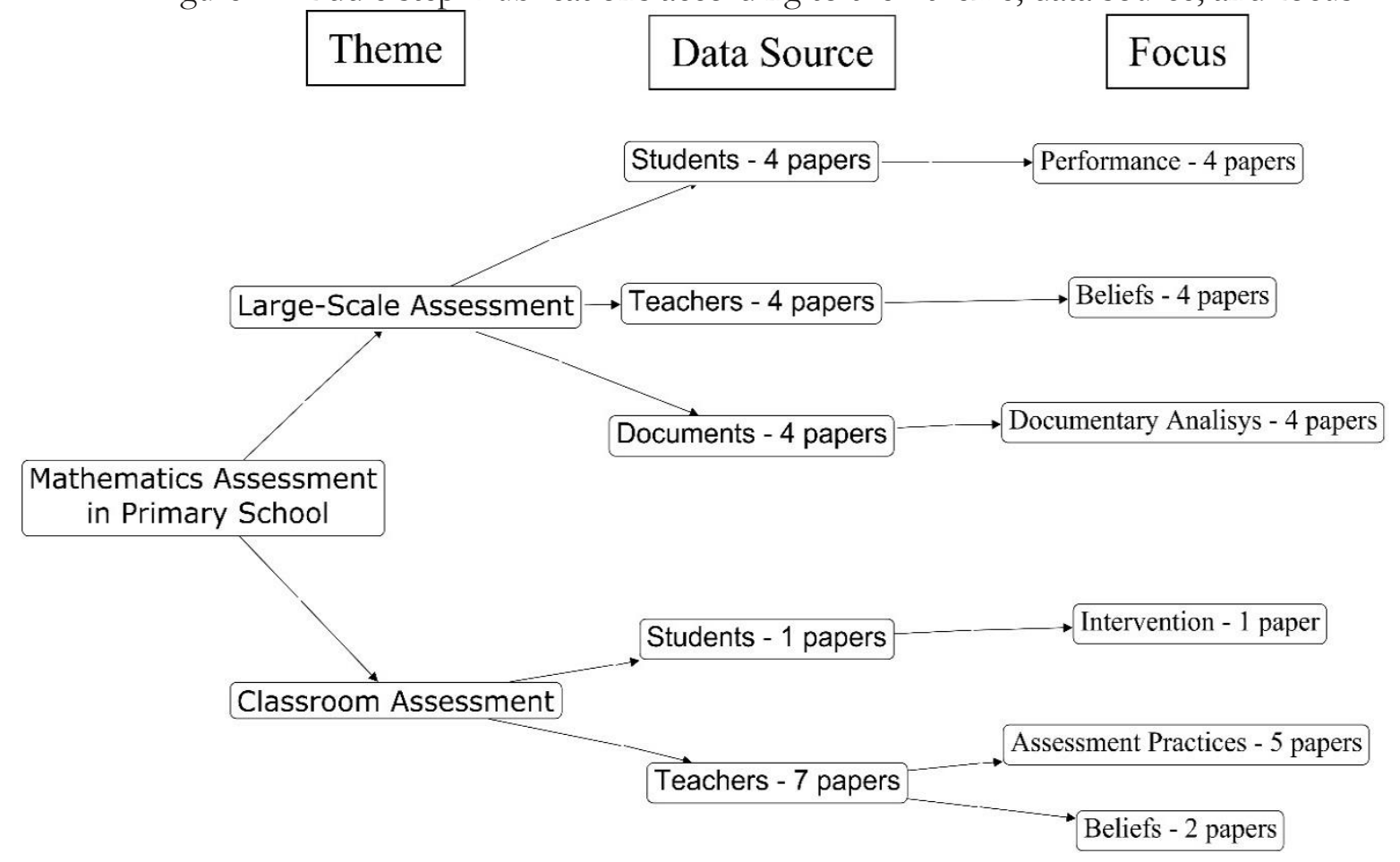

The next step in the 20 publications had identified the goals, the method, and results. Because our research questions were focused on teachers' assessment practices and beliefs, we also decided to exclude publications that had its data sources at students to concentrate only on teachers. After this, a new reading was done to select those publications that either addressed teachers' assessment practices or the teachers' beliefs on assessment.

\footnotetext{
11 http://catalogodeteses.capes.gov.br/catalogo-teses/\#!/
} 
TABLE 1. Publications on assessment in primary school mathematics education in Brazil published between 2010 and 2017.

\begin{tabular}{|c|c|c|c|c|}
\hline & & \multicolumn{3}{|c|}{ Focus of the publication } \\
\hline & & $\begin{array}{l}\text { Teachers' } \\
\text { assessment beliefs }\end{array}$ & Assessment practices & Both \\
\hline \multirow{2}{*}{$\begin{array}{l}\text { Type of } \\
\text { assessment }\end{array}$} & $\begin{array}{l}\text { Large-scale } \\
\text { assessment }\end{array}$ & $\begin{array}{l}\text { Blengini }(2015)^{*} \\
\text { Matos }(2012)^{*} \\
\text { Martins }(2012)^{*} \\
\text { Oliveira }(2012)^{*}\end{array}$ & & \\
\hline & $\begin{array}{l}\text { Classroom } \\
\text { assessment }\end{array}$ & $\begin{array}{l}\text { Silva }(2014)^{*} \\
\text { Zanon }(2011)^{*}\end{array}$ & $\begin{array}{l}\text { Borralho \& Lucena (2015)** } \\
\text { Mandarino (2012)** }\end{array}$ & $\begin{array}{l}\text { Costa }(2013)^{*} \\
\text { Barbosa (2013)** } \\
\text { Côrtes \& Muniz } \\
(2016)^{* *}\end{array}$ \\
\hline
\end{tabular}

\footnotetext{
* Master's dissertation

** Conference paper
}

In the end, the search for and selection of relevant publications resulted in 11 publications to be included in the review (see Table 1): four publications on large-scale assessment and seven on classroom assessment. The publications on large-scale assessment all deal with teachers' beliefs, while the publications on classroom assessment either are addressing teachers' beliefs or their assessment practices or with both.

\section{Analysis Procedure for Comparing the Findings from the Curriculum Documents Analysis and the Literature Review}

To investigate the relationships between the findings of the curriculum documents analysis and the assessment practices found in the research papers, we proceeded our analysis by using the three steps proposed by Bardin (2016): pre-analysis that consisted of the selection and organization of the material; exploration of the material with reading and coding and; the third step consisted of treating the results that were later analyzed.

To determine the conceptualizations of assessment described in the Brazilian curriculum document PCN (Ministério da Educação, 1997), we identified the main themes in this document such as assessment practices, ongoing process, and connection with goals, dealing with errors, and standards to be measured.

To figure out what research has revealed Brazilian assessment practice and teachers' beliefs on assessment, we summarized each of the selected publications taking the type of assessment as a starting point. Then we analyzed the papers by focus, assessment practice, and teachers' beliefs on assessment, in two sections of findings related to large-scale assessment and classroom assessment.

To understand the relation between the conceptualization of assessment in the PCN and teacher' assessment beliefs and practices as found in published research, we compared the findings from both. It means that we looked in the PCN, in a similar way as in the literature review, to reveal the guidelines for the assessment practices to be used, the recommended assessment processes and goals, and the suggestions that are given for how to deal with errors and the standards to be measured.

\section{RESULTS}

\section{Results from the Curriculum Documents Analysis: Assessment in Brazilian Primary School Mathematics Curriculum}

The PCN reflect a broad interpretation of assessment, explaining that assessment should focus on a wide variety of aspects related to student performance, in terms of the acquisition of conceptual and procedural understanding and attitudes. In addition to classroom assessment, it also 
includes evaluating other aspects of education, such as the selection of instructional content, instructional practice, and material conditions of the educational work in schools.

What the assessment practice of mathematics teachers should look like is explained in the PCN in a short section called "Assessment in Mathematics" (Ministério da Educação, 1997, p. 41). This section states that changing the goals of primary school, changing the way of teaching mathematics, and changing the taught content imply rethinking the purposes of assessment regarding what and how to assess. Moreover, the PCN explicitly describe the importance of teachers being aware of their conceptions of mathematics, classroom practice, of pedagogical choices, and their objectives and contents of teaching. Additionally, teachers' assessment practices should be closely linked to these conceptions. In the PCN, the assessment practices, the ongoing process, and connection with goals, dealing with errors, and standards to be measured are mentioned as the four main aspects of teachers' assessment practice.

\section{Assessment Practices}

The PCN mention different practices that can be used by teachers to assess students. Assessments can be carried out as a test, schoolwork (e.g., monograph, oral presentation), and observing students' attitudes in the classroom. The information gathered through these assessment practices should be considered as possible evidence of the acquired competences. The PCN provide examples of how teachers can create tools to record their observations about students.

\section{Ongoing Process and Connection with Goals}

Through observation and dialogue, teachers should seek to identify their students' thinking. According to the PCN, teachers should permanently interpret signs of evidence, allowing them to form judgments about their students' skills and understanding, which can further allow them to reorganize their instruction. By gathering evidence of what their students do not understand, they can choose to intervene and assist them. Essential in this respect is the connection with the educational goals. To increase the quality of evidence about student performance, the teachers must be clear about what they intend students to achieve and how to use evidence to decide whether students have reached these goals. In this sense, error analysis is suggested as an interesting and effective tool.

\section{Dealing with Errors}

As expressed in the PCN, making errors inevitably belongs to the process of learning and can often be interpreted as a way to achieve success. Different factors may be the cause of a mistake. According to the PCN, students who missed the result of 126-39 might not understand the place value concept. They could have subtracted 6 from 9, based on the idea that, in subtraction, the smaller number is always removed from the larger number. Or maybe they could have randomly given a number as the answer showing that they did not understand the meaning of the given problem. Alternatively, they could have used an erroneous calculation procedure or could have made a miscalculation by lack of basic skills. When the teachers have identified the cause of errors, they have to plan an appropriate intervention to assist the students in developing further understanding. In addition to giving further instruction to the class as a whole, for some students, it might be helpful to individually point out their mistakes and explain again how to solve the problems correctly.

\section{Standards to Be Measured}

Finally, the PCN also express the mathematical skills and understanding primary school students should have, and that, thus, should be assessed. An example is in Table 2.

TABLE 2. Excerpt of Brazilian Mathematics Assessment Standards for Primary Schools; adapted from PCN (Ministério da Educação, 1997, pp. 53, 63).

\begin{tabular}{lll|ll}
\hline \multicolumn{3}{c|}{$1^{\text {st }}$ and $2^{\text {nd }}$ grades } & \multicolumn{3}{c}{$3^{\text {th }}$ and $4^{\text {th }}$ grades } \\
\hline Solving context problems involving & counting and & Solving context problems involving counting and \\
\hline
\end{tabular}


measuring, understanding meanings of operations, and selecting calculation strategies.

Students can solve context problems that are expressed orally, textually, or symbolically, and use their knowledge of numbers, measures, and understanding of the meanings of operations by using an own or standard calculation strategy. The focus should mainly be on problems with addition and subtraction situations. measuring, understanding meanings of operations, and selecting calculation strategies.

Students can solve context problems by using their knowledge of natural and rational (fractional and decimal) numbers, and understanding of the meanings of operations, by using an own or standard calculation strategy, and by justifying both the solution processes as the calculation strategy according to the context situation.

In addition to these content standards, the PCN also provide guidelines for mapping the development of students' learning attitudes. For example, the following attitudes are illustrated: solving problems by your own means, asking questions, using creative or conventional strategies, justifying the obtained answers, communicating your solutions, participating in group work, helping others with problem-solving, asking for explanations, and many more.

\section{Results from the Literature Review: Brazilian Primary School Teachers' Mathematics Assessment Practices and Beliefs}

\section{Findings Related to Large-Scale Assessment}

Four studies focused on teachers' opinions and beliefs about the results and usefulness of large-scale assessments. Matos (2012) investigated primary school teachers' ideas about student results on the Prova Brasil. They administered a questionnaire which was answered by 17 teachers from schools in the northeastern region of Brazil. Most teachers appeared not to understand the results of this assessment and were rather opposed to a test, only focusing on problem-solving like Prova Brasil. For the teachers, problem-solving was just one of the many methodologies they use in their mathematics classes. It also became clear that the teachers were not familiar with the standards that were used to develop the Prova Brasil, which were based on the PCN.

In Oliveira's (2012) study, teachers' ideas about using the Provinha Brasils results were investigated by teacher interviews. Through interviews conducted individually with five teachers, she investigated how the teachers analyzed their students' understanding based on the answers they gave to the items that involved statistics and their suggestions for activities to overcome difficulties. The teachers considered the test items as a kind of curriculum, stating that they especially teach the content in the items. These five teachers had difficulties with interpreting the results of the Provinha Brasil test. They were unable to identify the relationships between different contents and skills in the assessment items of this large-scale test. According to the author, teachers have to be better prepared for the use of the results of the Provinha Brasil to avoid misinterpretations. Furthermore, because many teachers wrongfully attributed students' mistakes to particular misconceptions, it is necessary to complement their mathematical training.

Martins (2015) investigated utilizing interviews teachers' opinions about a different largescale assessment, namely the Saresp, the external assessment used in São Paulo state. The publication of the results of this large-scale assessment bothered teachers as it leads to comparisons between schools in terms of their results. Additionally, the teachers considered it unfair that the state guided its educational policies by the results of this external assessment. They were also rather divided about the usefulness of the assessment results.

Finally, Blengini (2015) interviewed primary school teachers, focusing on their beliefs about the importance of external large-scale assessments for the quality of education. The teachers were not in favor of such external evaluations because they believed them to be a form of control, which could interfere with the school's choices concerning the curriculum content. It was clear for them that the evaluation model used was more a measuring instrument than an assessment tool seeking to help the students' difficulties in the schools because the results were not provided to schools in such a way that they could be used in the assessment and teaching process.

The results of these four studies highlight that the teachers are not convinced about the usefulness of large-scale assessments. They appeared to consider external assessments as state 
intervention in school and doubted the effectiveness of this type of evaluation. Moreover, the studies showed that many teachers were not able to understand the assessment results and relate the standards of the tests to the school curriculum. Therefore, the researchers concluded that it is necessary to improve teacher education and offer opportunities for professional development on teachers' mathematical knowledge (for teaching).

\section{Findings Related to Classroom Assessment}

Seven studies focused on teachers' classroom assessment beliefs and practices. In a questionnaire study, Mandarino (2012) investigated how often teachers whose students participated in the Prova Brasil adopted a particular correction style in their own assessment practice. Four groups of teachers were distinguished according to the type of correction they favored.

In the first group, Mandarino (2012) grouped the teachers that individually corrected student activities by checking students' notebooks or collecting individual activities to be corrected overtime. Teachers from the second group collectively corrected on the blackboard, and the students correct their notebooks themselves. In the third group, the predominant correction was collective and happened on the blackboard by the teachers through discussing problems in which students had difficulties. At times, students were also called upon to present their answers on the blackboard. The teachers in the fourth group most often did the written correction on the blackboard, asking the solutions from the students. These teachers did not make individualized corrections of student activities or notebooks.

Based on these results, Mandarino (2012) considered that also several other factors, such as the types of activities that are proposed, the used textbook, and what the teachers do while students solve tasks, should be taken into account when interpreting the correction style a teacher adopts. Furthermore, regarding self-regulation procedures, she raised the concern that, from the earliest years of schooling, students should develop self-confidence in their mathematics knowledge and have the autonomy to create and test hypotheses, which means that they must be allowed to solve a problem and validate their responses.

Costa (2013) investigated the assessment practices of 5th grade primary school teachers by providing a questionnaire to nineteen teachers and interviewing and observing two teachers. Teachers assessed students' learning mostly with paper-and-pencil tests. They also observed students' activities in an informal and unsystematic way. Some teachers pointed out that they evaluated their teaching daily, by doing and redoing their practices. They considered classroom assessment to be part of democratic teaching practices that were generally not carried out systematically but spontaneously. One teacher said that she thinks that it is necessary to prepare students for large-scale assessments preparing students for the external test by practicing similar problems in the classroom. Furthermore, she explained that adopting this procedure as a routine makes it easier for students to solve the test.

Costa's (2013) comment on what she found in her study is that teachers could mobilize many important classroom activities as assessment moments, such as homework and other production of written records by students (texts in games and group activities). According to the author, these are activities that can provide the teacher with evidence about students' knowledge. She concluded that it is necessary to improve mathematics assessment and that continuous education should build on teachers' current assessment practices, possibly leading to reflection on, and systematic appropriation of, new teaching guidelines.

Borralho and Lucena (2015) investigated the relations between teaching and assessment practices and the improvement of students' learning by classroom observations and interviews with teachers in Portugal and Brazil. In both countries, teachers did not use formative assessments much in their teaching. The assessment was not deliberately, systematically, or consciously present in the teachers' instruction. Teachers' use of assessment was sporadic and not focused. They did not use assessment to plan and replan their practices and generally also not to improve students' learning. The instruments used were summative tests, complemented by appreciations of student activities carried out in the classroom. These assessments were mostly aimed at classifying and grading students at the end of the school period. 
Using a questionnaire with open-ended questions, Barbosa (2013) investigated what the beliefs on assessment in mathematics were and which were the assessment instruments used by nine primary school teachers of a public school in the Brazilian Southeast region. Most of them considered assessment useful for diagnosing students' learning and used day-to-day activities, such as participation in class and the use of concrete material, to assess their students' learning. Other teachers, who believed assessment to be a measure of student knowledge, used more formal assessment activities, such as bimonthly tests. Concerning how to deal with errors, four teachers believed that students' mistakes are a way of guiding further instruction. By looking at correct and incorrect answers, teachers can achieve a better understanding of students' learning. Five teachers saw errors as help in making students aware of their achievement and their need for improvement.

Côrtes and Muniz (2016) analyzed two teachers' mathematics assessment practices as observed in their classrooms and their assessment beliefs, as expressed in a semi-structured interview, group meetings, and observations. The only formal assessment instruments that both teachers used were bimonthly written tests. The questions in these tests were reproductions of tasks that had been taught in the classroom. Also, from the observations, it seemed that the assessment was mostly used to measure student learning. Teachers used a linear approach to the content to be taught and used tests to assess at the end of this process. The authors believed that it is necessary to make the schools' pedagogical coordinators responsible for the in-service education and consolidation of teachers' collective work. Furthermore, they emphasized that it is essential to further elaborate assessment in mathematics by promoting the interaction between students, discussing different processes and solution strategies, and offering metacognitive hints to the students. Finally, they advocated that by mobilizing students' knowledge, creating chances, being free to make mistakes, thinking about mistakes, and creating the necessary experiences, teaching, and learning mathematics will have more meaning.

Zanon (2011) used questionnaires and group meetings to understand primary school teachers' knowledge, beliefs, and conceptions about mathematics and its assessment. Participants were 23 teachers who worked in rural schools in the east of Brazil. They believed that assessment should happen in a procedural way, that it is an instrument to verify student learning, and that it is necessary despite being permeated by negative feelings and effects. The teachers had difficulties and doubts about the specific content of mathematics. The author also noted that the teachers had a traditional view of mathematics assessment and negatively felt about them. To assess their students, most participants mentioned classroom games, individual tests, and mechanical mathematics activities in the classroom and by homework, supplemented by individual observation of the students' work. The author advised that it is necessary to teach with understanding and to provide continuous education to teachers about effective assessment problems and the metacognitive processes of teaching, learning, and assessment in mathematics.

Silva (2014) investigated how assessment contributed to mathematics teaching in a primary school in the South Region of Brazil. Assessment activities were used in the planning of a school trip with 5th grade students. As an assessment instrument, the teacher used the students' competence of data collection and the clarity of organizing the data. In a newspaper format, the students had to present the results of the data collection using graphs and a small explanatory text. The study revealed that the teacher' conceptions of assessment were broad and permeated the entire process of teaching and learning. The author stated that when the teachers take the role of teacher-researchers, they may be teaching supported by knowledge gained through the constant assessment of their instructional practice and student learning. She concluded that ongoing assessment, providing the teachers with more insight into student learning during teaching, was fundamental for improving the quality of teaching and, consequently, teacher and student learning.

When considering the seven studies, it seems that classroom assessment practices did not happen systematically and mostly occurred spontaneously, such as observing student activities without a established plan. Nevertheless, teachers' beliefs about mathematical assessment in primary school include that assessment is used to verify students' learning and should be part of a process. These beliefs are complemented on the one hand by the idea that assessment is necessary despite being 
permeated by negative feelings (Zanon, 2011). And on the other hand, the idea that assessment creates the link between teaching and learning, meaning that assessing during teaching, is fundamental to improve teaching and student learning (Silva, 2014).

When comparing assessment practices with assessment beliefs, in these studies, we can see a mismatch between what is done and what Brazilian primary school teachers think. The results from research into teachers' beliefs mostly indicate that teachers believe classroom assessment to be a process that occurs in many moments during the teaching process and by using different instruments (Barbosa, 2013; Costa, 2013; Zanon, 2011). Nevertheless, the most used practices are testing students at the end of a school period (Borralho \& Lucena, 2015; Côrtes \& Muniz, 2016; Costa, 2013; Zanon, 2011). Considering the recommendations of the researchers, they mainly point to improving teachers' in-service education.

\section{Teachers' Mathematics Assessment Practices and Beliefs Related to Assessment as Described in the Brazilian Mathematics Curriculum}

\section{Assessment Practices, Process, and Goals according to PCN Compared to What Teachers Do and Believe}

The PCN recommend that assessment has to be considered part of the teaching and learning process. That is, the PCN indicate the need for multiple assessment tools and various procedures to assess. Therefore, assessments should be done many times during the learning process and with a variety of tools, such as tests, schoolwork, and observing students' attitudes. For example, the PCN suggest teachers to use a portfolio to make an inventory of the progress or setbacks of each student in learning mathematics. However, this suggestion was not mentioned as an assessment practice in any of the Brazilian research articles. The need for multiple assessment tools was mentioned by Costa (2013). She commented that teachers could mobilize many important classroom activities as assessment moments because it provides teachers with evidence about students' knowledge.

Similarly, Silva (2014) and Cortês and Muniz (2016) recommended encouraging teachers to think as researchers in the classroom to assess pedagogical practices and students' learning continually. It could promote students and professional development. Notwithstanding this recommendation, the results of Costas' (2013) study showed that teachers used assessment in a spontaneous and unsystematic way, so not much like researchers.

Besides that, the PCN also advocate emphatically in various parts of the document (Ministério da Educação, 1997, pp. 50, 52, 58, 62) is that students need to gain confidence in their ability to learn mathematics. However, only Zanon (2011) underlined the importance of the teacher being able to deal with the feelings of the students to mathematics.

Although Brazil has a national assessment system, the PCN do not address large-scale assessment directly. The research into the Prova Brasil large-scale assessment (Blengini, 2015; Martins, 2015) showed that the publication of this examination's results bothered teachers as it led to comparisons among schools - that is more connected with the goals of a classificatory assessment. The researchers evidenced that the Prova Brasil model is more a measuring instrument than an assessment tool that seeks to alleviate students' difficulties in schools.

As evidenced in the reviewed research, teachers believe that mathematics assessment in primary school is used to attest students learning and is an ongoing process. Contrastingly the PCN describe that continuous assessment during mathematics instruction is fundamental to improving the organization of teaching and learning of students and permeates the whole movement of teaching and learning. Based on the reviewed research, this does not seem to be what happens in Brazilian primary school.

\section{Dealing with Errors according to PCN Compared to What Teachers Do and Believe}

On error, the PCN warn that it is considered as an aspect to be investigated by the teacher: "When the teacher can identify the cause of the error, he/she plans the appropriate intervention to help the student to evaluate the path followed" (Ministério da Educação, 1997, p. 41). In some 
research, assessment in mathematics has been seen as linked to what teachers think about students' mistakes. Teachers' beliefs were described, such as the error shows the teachers what and how to teach, what should be more worked on with the students, and the error highlights the students' difficulties and what students still need to improve. Some teachers see the error as a vital element to aid teaching, whereas other teachers describe the error as a difficulty of the student.

In agreement with PCN, an example was given by Costa (2013): a teacher corrects the tests, and on the same day that they were applied, he gives it back to the students for a discussion about their solutions - what would favor learning. However, the grade given by the teacher does not change. That means, even though the test was later used for a discussion of solutions, it still was used as a classificatory assessing instrument of students. This is an example by which we can infer that a formative assessment in the classroom is under construction but is not yet fully effective in the mathematical assessment practices carried out in Brazilian primary schools. We advocate that teachers need possibilities to learn how to assess, similar to Berry (2011):

To make assessment a useful tool for teaching and learning, it is necessary to empower the teachers with knowledge and skills. What the teachers urgently need are, in addition to the overarching assessment policies, guidelines and directives, concrete ideas on how to translate the assessment for learning concepts into classroom actions, including, for example, detailed techniques for implementing assessment for learning in classroom situations (Berry, 2011, p. 100).

\section{Standards to Be Measured according to PCN Compared to What Teachers Do and Believe}

As the official document that aims to guide the curriculum in schools, the PCN guide the elaboration of the Prova Brasil exam by INEP and should thus support the teachers' classroom lessons. Nevertheless, the teachers were not familiar with the standards that were used to elaborate the Prova Brasil (Matos, 2012), and they considered the test items to be indicative of a curriculum (Oliveira, 2012). Blengini (2015) found that teachers were not in favor of external assessments because they believed them to be a form of control that could interfere with the school's choices of the content of the curriculum. If the test standards were created by INEP from the PCN and they do not know them, then we can infer that they probably also do not know the PCN.

Concerning large-scale assessment, there was a lack of consensus among teachers. They believed that external assessments were a government intervention in schools, and they had doubts about the effectiveness of this type of assessment. However, some teachers thought that large-scale assessment systems are necessary to ensure the quality of education.

\section{Recommendations Found in the PCN and the Reviewed Research Regarding Mathematics Teaching and Assessment}

The PCN affirm that some of the problems interconnected to mathematics teaching are related to the process of teacher education, in both initial and in-service education.

As a result of the problems of teachers' education, practices in the classroom are based on textbooks, which, unfortunately, are often of unsatisfactory quality. The implantation of innovative proposals, in turn, faces the lack of qualified professional education, in the existence of inadequate pedagogical conceptions, and also in the restrictions related to working conditions (Ministério da Educação, 1997, p.22).

Most of the research covered in our review recommended aspects to be improved in mathematics teaching through teacher education. According to Côrtes and Muniz (2016), in-service education is the responsibility of the pedagogical school staff by which they foster training within schools and consolidate the collective work of the teachers. Other researchers did not explain how to do the teachers' in-service education but emphasized the kind of knowledge that is important to study with teachers. Thus, Barbosa (2013) recommended teachers to learn about the use of multiple assessment tools, which might be working in favor of learning. Zanon (2011) considered it would be important that in-service education actions involved affective issues and metacognitive processes of teaching, learning, and assessment. Due to the complexity of classrooms and teaching practices, 
Mandarino (2012) recommended studying the different teachers' practices of task corrections and relating it to the types of activity that are proposed to students, the textbook, what the teacher does while his students are solving the exercises, and among many others. Costa (2013) pointed out that inservice education should emphasize more the teachers' current practice to reflect upon and to systematically appropriate teaching guidelines of mathematics education.

Initial teaching education was also mentioned by Costa (2013) because the research results informed that assessment was not a content present in the curricula of the universities, especially assessment in mathematics education. Gatti et al. (2010) examined various Pedagogy courses in Brazil. They found a few assessment courses in the content of the subjects of basic education (Literacy, Portuguese Language, Mathematics, History, Geography, Arts, Science, Physical Education). The assessment was only treated sporadically in training courses, and if it were, then only general or superficial aspects were addressed, thus suggesting a fragile association with teaching practices.

As recommended by the PCN, Brazilian research also brought as conclusions and recommendations that it is necessary to improve teachers' education. However, the researchers justify this need to enhance the knowledge of mathematics teachers in the initial years of elementary school differently from the reasons pointed out by PCN:

- teachers do not understand the results generated by large-scale assessments and cannot make a relation between school curriculum and test's reference standards; and,

- teachers attribute student's mistakes to misconceptions they had about some content.

Also, the researchers recommend that teacher education:

- clarify the assessment structure, methodology, and objectives, which makes the process of understanding and using the results easier; assessment items;

- identify the relationships between different contents and skills present in the large-scale

- discuss how to use the results of the large-scale assessment as an element of their planning to promote assessment to learning;

- discuss, plan and carry out activities involving teach math skills;

- complement teachers' training about mathematical knowledge;

- reflect on the practice developed by teachers; and

- introduce new teaching guidelines.

\section{CONCLUSION}

In our study, we found 11 publications on beliefs and assessment practices of elementary school teachers in mathematics. The teachers' beliefs and assessment practices reflected in these publications indicate that large-scale assessments, even if not approved by all teachers, influence changes in the teaching program, such as adding content or emphasizing specific content. As a result, teachers instruct students to study the test questions. Therefore, what teachers teach ends up being dictated by external assessments, which teachers also consider to be the national educational policy. The consequences that follow from this approach are not always appropriate for the educational context.

Our review of the research literature showed that classroom assessment practices are usually carried out spontaneously without a clear assessment objective previously formulated and do not occur systematically. They are mainly on-the-fly assessment when the teachers follow the activities carried out by the students and are surprised by a student's response. The assessment practices cited in the papers are daily school activities, daily corrections of mathematical tasks, students' participation in the classroom, observing students' reasoning, and students' activities. These practices refer to the assessment recommended by the curriculum documents, such as the PCN, which have much in common with the principles of formative assessment.

However, the results of the studied papers indicate that mathematics assessment practices in the Brazilian primary school still keep some distance from the formative approach to assessment. It seems that even much has to be done to ensure that formative assessment practices reach mathematics classrooms, especially in terms of how to teach so that the student learns. Despite the beliefs of 
Brazilian teachers of assessment as a process to improve teaching and learning, it seems that the mathematics assessment practices carried out in schools do not yet favor the assessment for learning. Still, the mathematics assessment practices are used mainly as an instrument of assessment of learning, that is, to determine the evaluation of students at the end of a school period.

Based on our findings, research that listens to what teachers have to say about their desires and difficulties about classroom mathematical assessment should occur in greater quantity and scope. We recommend a public policy in which teachers have opportunities for professional development, focusing on assessment and, mainly, on the concepts of formative assessment in mathematics education. The in-service education should also promote discussions about current assessment practices and tools so that formative assessment can actually be implemented in Brazilian mathematics classrooms.

\section{ACKNOWLEDGMENTS}

We thank the Coordination for the Improvement of Higher Education Personnel - CAPES/Brazil (http://www.capes.br) for the scholarship to Jutta Cornelia Reuwsaat Justo (Postdoctoral Research/ Process $n^{\circ}$ 88881.120678/2016-01) and Ednei Luís Becher (Sandwich Doctoral Program/ Process $n^{\circ}$ 88881.133333/2016-01). We would also like to thank the Lutheran University of Brazil (ULBRA) and Utrecht University (UU) for making possible our studies in the Netherlands.

\section{REFERENCES (UPPERCASE, BOLD, FONT GARAMOND 12, LEFT-ALIGNED)}

Bardin, L. (2016). Análise de conteúdo. Trad. Luís Antero Reto e Augusto Pinheiro. São Paulo: Edições 70.

Barbosa, J. K. (2013). Concepções de avaliação em Matemática de professores de uma escola pública do Vale do Ribeira/SP. Anais do XI Encontro Nacional de Educação Matemática. Sbem: Curitiba.

Berry, R. (2011). Assessment reforms around the world. In R. Berry, \& B. Adamson (Eds.), Assessment reform in education (pp. 89-102). Netherlands: Springer.

Blengini, G. D. (2015). Trabalho docente e qualidade da educação: dificuldades encontradas por professores dos anos iniciais do ensino fundamental. Dissertação (Mestrado). Universidade Federal de São Carlos. São Carlos, São Paulo.

Borralho, A. \& Lucena, I. (2015). Avaliação e Ensino na Educação Básica em Portugal e no Brasil: Relações com as Aprendizagens (AERA). Anais do VI SIPEM, Pirenópolis, Goiás.

Côrtes, S. \& Muniz, C. A. (2016). Considerações sobre a organização e o desenvolvimento curricular pelo professor e sua relação com o processo de ensino e aprendizagem de Matemática nos anos iniciais. In: Anais do XII Encontro Nacional de Educação Matemática. Sbem: São Paulo.

Costa, A. F. G. (2013). Práticas avaliativas em Matemática de professores do Ensino Fundamental: aproximações e distanciamentos em relação às recomendações da Educação Matemática. Dissertação (Mestrado). Programa de Pós-Graduação em Educação. Universidade Estadual Paulista, Presidente Prudente, São Paulo.

Gatti, B., Nunes, M. M. R., Gimenes, N. A. S., Tartuce, G. L. B. P. \& Unbehaum, S. G. (2010). Formação de Professores para o Ensino Fundamental: instituições formadoras e seus currículos. In: Estudos e Pesquisas Educacionais. São Paulo: Fundação Victor Civita, v. I. pp. 95-138. 
Mandarino, M. C. F. (2012). Práticas de correção da produção de alunos em fase de alfabetização: relações e revelações. In: Anais do $V$ Seminário Internacional de Pesquisa em Educaşão Matemática. Sbem: Petrópolis, Rio de Janeiro.

Martins, P. P. U. (2015). Políticas públicas de avaliação na perspectiva docente: desdobramentos da Provinha Brasil, Prova Brasil e SARESP para o trabalho de professores dos anos iniciais do ensino fundamental. Dissertação (Mestrado). Universidade Federal de São Carlos. São Carlos, São Paulo.

Matos, A. M. S. (2012). Prova Brasil: concepções dos professores sobre a avaliação do rendimento escolar e o ensino de matemática no município de Aracaju (SE). Dissertação (Mestrado). Universidade Federal de Sergipe. Aracaju, Sergipe.

Ministério da Educação. (1997). Parâmetros curriculares nacionais: matemática. Brasília, Brasil: MEC/SEF.

Ministério da Educação. (2017). Base Nacional Comum Curricular. Brasília: MEC. Disponível em: <http://basenacionalcomum.mec.gov.br/images/BNCC_20dez_site.pdf. Acesso em: 01 fev. 2018.

Oliveira, P. N. (2012). A provinha Brasil de matemática e o conhecimento estatístico: instrumento avaliativo a ser utilizado pelo professor? Dissertação (Mestrado). Programa de Pós-Graduação em Educação Matemática e Tecnológica. Universidade Federal de Pernambuco. Recife, Pernambuco.

Oliveira, P. R. G. (2014) Alfabetização matemática nos anos iniciais do ensino fundamental: uma leitura dos resultados da pesquisa GERES 2005. Dissertação (Mestrado), Faculdade de Educação da Baixada Fluminense, Universidade do Estado do Rio de Janeiro.

Shepard, L. A. (2000). The role of assessment in a learning culture. Educational Researcher, 29(7), 4-14.

Silva, D. S. G. (2014) A avaliação do movimento de ensinar e aprender matemática nos anos iniciais do Ensino Fundamental. Dissertação (Mestrado). Programa de Pós-Graduação em Educação. Universidade Federal de Santa Maria. Santa Maria, Rio Grande do Sul. 118 p.

Suurtamm, C., Koch, M., \& Arden, A. (2010). Teachers' assessment practices in mathematics: Classrooms in the context of reform. Assessment in Education: Principles, Policy \& Practice, 17(4), pp. 399417.

Van den Heuvel-Panhuizen, M. (1996). Assessment and Realistic Mathematics Education. Utrecht, the Netherlands: CD Beta Press.

Van den Heuvel-Panhuizen, M. \& Becker, J. (2003). Towards a didactic model for assessment design in mathematics education. In A. J. Bishop, M. A. Clements, C. Keitel, J. Kilpatrick, and F. K. S. Leung (Eds.), Second international handbook of mathematics Education (pp. 689-716). Dordrecht, the Netherlands: Kluwer Academic Publishers.

Veldhuis M. \& Van den Heuvel-Panhuizen, M. (2014). Primary School Teachers' Assessment Profiles in Mathematics Education. PLoS ONE, 9(1): e86817.

Zanon, T. X. D. (2011). Formação continuada de professores que ensinam Matemática: o que pensam e sentem sobre ensino, aprendizagem e avaliação. Dissertação (Mestrado). Programa de Pós-Graduação em Educação. Universidade Federal do Espírito Santo. Vitória, Espírito Santo. 
Submission: $21 / 08 / 2018$

Approval: 09/09/2020

${ }^{\mathrm{i}}$ A reduced version of this article was presented and published in the Proceedings of the VII International Seminar on Research in Mathematics Education (VII SIPEM) that took place in Foz do Iguaçu, Paraná, Brazil, November 04-08, 2018. 